Western University

Scholarship@Western

Aboriginal Policy Research Consortium International (APRCi)

$12-2012$

\title{
Tourists' Perceptions of Aboriginal Heritage Souvenirs
}

Janet Chang

Geoffrey Wall

Jul-Cheng (Richard) Hung

Follow this and additional works at: https://ir.lib.uwo.ca/aprci

Part of the Tourism Commons

Citation of this paper:

Chang, Janet; Wall, Geoffrey; and Hung, Jul-Cheng (Richard), "Tourists' Perceptions of Aboriginal Heritage Souvenirs" (2012).

Aboriginal Policy Research Consortium International (APRCi). 179.

https://ir.lib.uwo.ca/aprci/179 
This article was downloaded by: [University of Western Ontario]

On: 01 December 2012, At: 07:36

Publisher: Routledge

Informa Ltd Registered in England and Wales Registered Number: 1072954 Registered office:

Mortimer House, 37-41 Mortimer Street, London W1T 3J H, UK

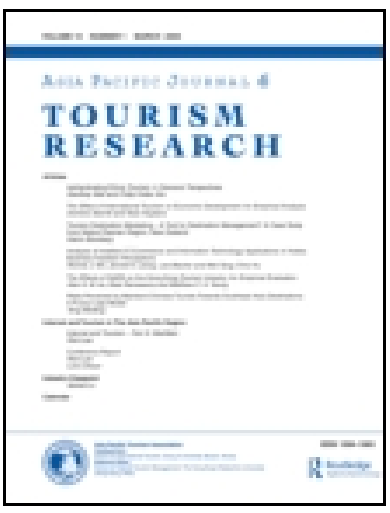

\title{
Asia Pacific J ournal of Tourism Research
}

Publication details, including instructions for authors and subscription information:

http:/ / www. tandfonline.com/loi/ rapt20

\section{Tourists' Perceptions of Aboriginal Heritage Souvenirs}

\author{
J anet Chang $^{a}$, Geoffrey Wall ${ }^{b} \&$ J ui-Cheng (Richard) Hung ${ }^{c}$ \\ ${ }^{a}$ Graduate Institute of Taiwan Food Culture, National Kaohsiung University \\ of Hospitality \& Tourism, Kaohsiung, Taiwan \\ ${ }^{b}$ Faculty of Environment, University of Waterloo, Waterloo, Ontario, \\ Canada, N2L $3 G 1$ \\ c Graduate Institute of Tourism Industry, Chinese Culture University, Taipei, \\ Taiwan \\ Version of record first published: 16 J an 2012.
}

To cite this article: J anet Chang, Geoffrey Wall \& J ui-Cheng (Richard) Hung (2012): Tourists' Perceptions of Aboriginal Heritage Souvenirs, Asia Pacific J ournal of Tourism Research, 17:6, 684-700

To link to this article: http:// dx. doi.org/ 10.1080/ 10941665.2011.640700

\section{PLEASE SCROLL DOWN FOR ARTICLE}

Full terms and conditions of use: http://www.tandfonline.com/page/terms-and-conditions

This article may be used for research, teaching, and private study purposes. Any substantial or systematic reproduction, redistribution, reselling, loan, sub-licensing, systematic supply, or distribution in any form to anyone is expressly forbidden.

The publisher does not give any warranty express or implied or make any representation that the contents will be complete or accurate or up to date. The accuracy of any instructions, formulae, and drug doses should be independently verified with primary sources. The publisher shall not be liable for any loss, actions, claims, proceedings, demand, or costs or damages whatsoever or howsoever caused arising directly or indirectly in connection with or arising out of the use of this material. 


\title{
Tourists' Perceptions of Aboriginal Heritage Souvenirs
}

\author{
Janet Chang ${ }^{1}$, Geoffrey Wall ${ }^{2 *}$ and Jui-Cheng (Richard) Hung ${ }^{3}$ \\ ${ }^{1}$ Graduate Institute of Taiwan Food Culture, National Kaohsiung University of Hospitality \& \\ Tourism, Kaohsiung, Taiwan; ${ }^{2}$ Faculty of Environment, University of Waterloo, \\ Waterloo, Ontario, Canada N2L 3G1; \\ ${ }^{3}$ Graduate Institute of Tourism Industry, Chinese Culture University, Taipei, Taiwan
}

\begin{abstract}
Heritage souvenirs are an indispensable part of indigenous tourism and the authenticity of indigenous heritage is a vital aspect of such tourism. This study adopts a mixed methods approach to explore the perceived authenticity of glass bead souvenirs of the Paiwan Tribe in Pintung County, Taiwan. The study explores differences in the evaluations of authenticity among stakeholders and the factors that influence perceptions of authenticity. An understanding of tourists' perceptions of indigenous heritage offers valuable information for the creation of indigenous souvenirs and for reviving the promotion of indigenous culture.
\end{abstract}

Key words: aboriginal tourism, heritage tourism, tourism souvenirs, perceived authenticity

\section{Introduction}

Tourism is often seen as a means of validating aboriginal cultures and enhancing their economic opportunities, but a substantial literature documents the provision of inauthentic experiences, negative impacts on host populations and, often, only superficial interest in aboriginal products on the part of visitors (Yang \& Wall, 2009; Yang, Wall, \& Smith, 2008). Although a wide variety of research has been undertaken on aboriginal tourism, drawing on such research undertaken primarily in Taiwan, it is argued that a more holistic approach is required if the complex layers of aboriginal tourism are to be better understood so that tourism might contribute more substantially to the enhancement of the wellbeing of these formerly majority, but now minority, people.

Both the supply- and demand-sides of aboriginal tourism have been explored. With

*Email: gwall@uwaterloo.ca 
respect to the former, issues such as how colonial forces (i.e. the 50 years of colonization by Japan) suppressed aboriginal culture and affected the abilities of aboriginal people to preserve their culture and to provide authentic experiences for visitors have been studied (Yoshimura \& Wall, 2010). Using weaving as an indicator and postcolonialism and gender as organizing constructs, the researchers explored how aboriginal identity has been modified by colonialism and tourism.

From the demand-side, issues such as the characteristics of tourists and their behaviors at aboriginal sites, their assessments of the authenticity of woven products and other souvenirs, and the extent to which such tourists seek novel experiences have been examined (Chang, Wall, \& Chang, 2008; Chang, Wall, \& Chu, 2006). Such studies have embraced cases where aboriginal tourism products are not the only ones available, as well as annual aboriginal festivals (e.g. the harvest celebration of the Rukai tribe in Taiwan) (Chang, 2006). However, a more comprehensive approach to understanding the demand for aboriginal heritage products has yet to be developed.

Heritage, in conjunction with history, habitants and handicraft, according to Smith (1996), are the essential components of the so-called "four Hs" of aboriginal tourism (Chang, Wall, \& Lai, 2005). Aboriginal handicrafts, as one type of souvenir, are important expressions of aboriginal culture, and their production, sale and authenticity has become an important area of research (Yang \& Wall, 2008). They are probably similar to other cultural tourism souvenirs in that they may be expected to provide material evidence to support the authentic experiences that visitors may be seeking when visiting tribal communities or, afterwards, as a tool to recall memories of those experiences. However, their role as links between visitors and aboriginal people may also make them different from other souvenirs.

Tourists and tourism destinations are connected by means of experiences, of which souvenirs may be tangible symbols, and perceived authenticity is likely to influence the quality of experiences that tourists gain from their visits (Apostolakis, 2003). The perceived authenticity of heritage has received substantial academic attention (Steiner \& Reisinger, 2006), and Chhabra, Healy, and Sills (2003) noted that perceptions of authenticity are positively related to tourist consumption, satisfaction and expenditure. Handicrafts, which often contain representations of aboriginal culture, have become popular souvenirs. As such, shopping for aboriginal souvenirs may reflect a desire to seek authenticity on the part of tourists (Hitchcock \& Teague, 2000).

The above discussion indicates that handicrafts may be an important means of communication between tourists and aborigines, but their meaning is varied and underexplored. Thus, this research aims to further understanding of aboriginal handicrafts from the perspectives of different stakeholders by using both qualitative and quantitative approaches. This involves the exploration of the perceived authenticity of aboriginal souvenirs between different stakeholders and among tourists with different attributes. Focusing on glass bead souvenirs, which are the most accessible handicraft of the Paiwan tribe in Taiwan, as an example, differences in evaluations of authenticity are examined.

\section{Literature Review}

\section{Cultural and Heritage Tourism}

Tourism research suffers from a plethora of imprecise terminologies. We regard cultural 
tourism as a broad category that embraces a variety of types of tourism, including heritage tourism. Both natural and cultural heritage have been widely discussed (Chhabra et al., 2003; Timothy \& Boyd, 2003). Heritage, by definition, refers to any objects, rituals or places that connect the past with the present and are passed down from generation to generation (Ramshaw \& Gammon, 2005). Similarly, Toyota (2006) indicated that heritage can be any valued objects or things, tangible or intangible, that are inherited and preserved for future generations. Graham, Ashworth, and Tunbridge (2000) have suggested that not all history becomes heritage, so heritage involves selection. Furthermore, in the tourism context, heritage is a product that is packaged and sold.

Heritage tourism is usually seen as being part of cultural tourism (Nuryanti, 1996). Goeldner and Ritchie (2002) saw aspects of heritage, including visits to archeological sites, architecture, monuments, industrial facilities, museums, musical performances and theaters, and culinary and ethnic attractions, as belonging to cultural tourism. Hall and Zepple (1990) explained that cultural tourism attractions include, but are not limited to, heritage travel districts, monuments and the lifestyles of heritage areas, whereas cultural tourism involves products of contemporary cultures, such as festival experiences and cuisine, as well as cultural expressions from the past. Aboriginal tourism is a form of cultural tourism that often has strong heritage components. It follows that much of the literature on cultural and heritage tourism is pertinent to aboriginal tourism. Thus, for example, Yale (1991) identified historically renowned architecture, handicrafts, beautiful scenery and even other travel activities as the contents of heritage tourism, as long as these are inherited or reflect the lives of ancestors.
Taylor (2001) suggested that heritage tourism refers to the consumption of contemporary tourists who engaged in varied activities connected to the past and the present, such as cultural landscapes, performances, cuisine and handicrafts. Recognizing that many types of tourist engage with such resources incidentally rather than on purpose, Poria, Butler, and Airey (2003) recommended that the term "heritage tourists" should refer only to those who are motivated to visit a place primarily because of its heritage. From a marketing perspective, Prentice (1993) suggested that heritage tourists are consumers who derive satisfactions from the benefits gained from heritage tourism, whereas producers provide products, as attractions, for them. Somewhat similarly, Fyall and Garrod (2001) defined heritage tourism as an economic behavior based on sociocultural resources to attract tourists. Such definitional conundrums are equally applicable to aboriginal tourism.

\section{Aboriginal Tourism}

Williams (1998) noted that culture is not static but is dynamic and adapts to changing circumstances. As such, a vibrant and creative society is continuously reconstructing its cultural foundation. Tourism is a force for change, and its introduction to aboriginal communities, whether sought or imposed, may have far-reaching consequences. For example, economic benefits may be acquired through business opportunities that are rooted in their unique cultures. At the same time, expressions of aboriginal culture, both traditional and novel, such as arts and crafts, dancing and singing, motifs and food, can be presented, interpreted, revised, transformed, recreated, re-presented and reinterpreted. Accordingly, aboriginal tourism, which 
involves interaction between tourists and indigenous people (Hsieh, 1999), is a special form of ethnic relations and it can be influential in re-forming and sometimes strengthening individual and group identity (Van den Berghe $\&$ Charles, 1992).

Hinch and Butler (1996) stated that aboriginal tourism is a form of tourism in which aborigines are directly involved and where the display of aspects of aboriginal culture is usually the essence of the attraction to tourists. Aboriginal cultures commonly contrast in many ways with those of mainstream society, and for many nonaborigines aboriginal tourism has an element of exoticism that can satisfy their desire to acquire novel experiences (Chang et al., 2006). A substantial literature addresses the attraction of aboriginal cultures to tourists and, thus, the cultural exoticism in clothing, arts and crafts, architecture, music, dance and other performances (Van den Berghe \& Charles, 1992).

While aboriginal or indigenous tourism can be viewed as being one type of ethnic tourism, the fundamental attraction to tourists is the exotic culture and a lifestyle that differs from their own (Yang \& Wall, 2009). Notzke (1999) found that tourists attending aboriginal tourism destinations in Canada were interested in aboriginal lives, arts, handicrafts, traditional activities, environments and food. In a different setting, Zeppel (1999) suggested that aboriginal attractions are often comprised of six elements: aborigines; aboriginal spirits or dreams; aboriginal architectural skills; aboriginal hunting skills; aboriginal cultural customs; and aboriginal handicrafts. Thus, Ryan and Huyton (2002) stated that aspects of traditional culture have been packaged and sold as tourism products. Tourists are likely to experience these with the help of interpretation by local aboriginal guides and take mementos in the form of souvenirs.

\section{Souvenirs}

Aboriginal souvenirs, whether based on traditional designs or tourists' expectations, are cultural symbols and their production and consumption are important aspects of aboriginal tourism. The word "souvenirs" has Latin origins and literally means "to come to mind". The word now refers to presents, gifts or local products of a destination that are mementos of a visit (Dougoud, 2000). Souvenirs are commonly linked with tourism: shopping for souvenirs is often part of travel experiences and their purchase makes a financial contribution to the destination economy (Jansen-Verbeke, 1998). Shopping, itself, is an important activity for many tourists (Goeldner \& Ritchie, 2002; Sirakaya et al., 2003). Souvenirs take many forms. Swanson (1994) defined souvenirs as substantial objects that often include postcards, T-shirts, products of nature, local handicrafts, gems or gem stones, toys, decorations or artworks, and the list might be easily extended.

Pine and Gilmore (1999) saw souvenirs as a means by which tourists recall and extend their experiences. They are evidence that a journey has been made and a way of sharing the experience with family and friends. They have similarities with photographs in that they are reminders of people, times and things that were encountered during the trip (Smith, 1996). From a destination-marketing perspective, they may represent the image of a destination (Schouten, 2006). Good souvenirs should reflect the sense of place of a tourism attraction (Stoffle \& Evans, 1990). Conversely, Hunter and Suh (2007) specified that "not-so-good" souvenirs do not provide social or economic value for destination societies. Souvenirs that are made locally, labeled to assure quality or have explanatory information attached are 
likely to have increased exchange values (Halewood \& Hannam, 2001). McIntosh and Goeldner (1995) suggested that tourists are inclined to pay extra for higher quality, more innovative or attractive souvenirs or presents. Many aboriginal communities have the potential to sell tangible representations of their culture as souvenirs should they wish to do so, thereby gaining an income by satisfying the desire of visitors for mementos.

\section{Authenticity}

Authenticity is often described as something that is genuine, traditional, real or unique (Sharpley, 1999). However, different people have different viewpoints and needs regarding authenticity, and consequently may evaluate it in different ways (Littrell et al., 1993; Redfoot, 1984). Thus, it is a subjective and socially constructed concept (Appadurai, 1986; Waitt, 2000). Although authenticity is a slippery term, the perception that it exists is important for the development of heritage tourism (Fischer, 1999; Waitt, 2000). In fact, perceptions of authenticity often contribute to the quality of heritage tourism experiences (Apostolakis, 2003; Chhabra et al., 2003; Cohen, $1988 \mathrm{a}, \mathrm{b})$, even though situations may be staged and distorted in an attempt to accommodate the needs of both tourists and local residents (Boorstin, 1992; Van den Berghe \& Charles, 1992). Staged authenticity may be used to establish communication between tourists and aboriginal people (MacCannell, 1976, as cited in Chhabra et al., 2003, p. 705). However, requirements for the provision of authentic experiences to visitors are greatly reduced owing to the neocolonial tendencies of global tourism (d'Hauteserre, 2010).

Perceptions of authenticity of experiences are receiving increasing attention in heritage tourism and are of particular interest in the marketing of cultural heritage sites (Steiner \& Reisinger, 2006). As in heritage and cultural tourism more generally, it is appropriate to explore aspects of authenticity in aboriginal tourism. The authenticity that many tourists are looking for (Chhabra et al., 2003; Taylor, 2001) exists in observing the lives of local people, their festivals and cultural rituals, handicrafts and other cultural expressions (MacCannell, 1973, as cited in Chhabra et al., 2003, p.705; Van den Berghe \& Charles, 1992). Authentic experiences are the ultimate goal for many tourists, and they are obtained through exposure to local environments and customs (Smith, 1996). Motivation to experience culture is an important antecedent of authenticity, which, in turn, influences tourist loyalty (Kolar \& Zabkar, 2009). According to Hitchcock and Teague (2000), many tourists perceive the act of seeking souvenirs as a search for authentic experiences. For such tourists, the search for authenticity is one of the main reasons to travel to a new place (Yeoman et al., 2007). Perceptions of authenticity have also been found to be positively related to tourists' satisfaction and expenditures (Chhabra et al., 2003).

Kerstetter et al. (2001) used the concept of specialization to explore the perceived authenticity of heritage tourism but found no significant relationships between tourists' perceptions and the degree of specialization. This result is inconsistent with the assertions of Goffman (1959) and Prentice (1993). To illustrate further, people may accept inauthentic experiences and are not necessarily against being "deceived" by reasonably fabricated things or objects. Nevertheless, management teams of tourism destinations are advised to manage authenticity in an effort to attract more tourists to spend more time in their sites. Using the potteries in Talavera, 
Mexico, as an example, Revilla and Dodd (2003) interviewed tourists and noted five elements existing in authenticity: "appearances or functions", "traditions and guarantees", "difficult to obtain", "locally made" and "inexpensiveness". Thus, authenticity can be broken down into a number of other attributes. Furthermore, tourists perceived authenticity mainly through appearances and functions of handicrafts. Asplet and Cooper (2000) studied tourists' purchasing behavior of Maori clothing as souvenirs and found that clothing containing traditional motifs or with labels of authenticity was favored by tourists. For international tourists, whether or not items were made locally is an important factor when considering authenticity.

Tourists are not, however, a homogeneous group and they may differ in their interpretations of authenticity. Hsieh (1999) noted that Han, the majority people in Taiwan, are in doubt regarding the authenticity of Atayal handicrafts. Anderson and Littrell (1995) explored the shopping behaviors of female tourists and found that age did not significantly influence the purchasing intention of tourism souvenirs. As long as tourism souvenirs are conceived as being as authentic as possible, all female tourists are inclined to purchase.

Time is also a factor. From a cultural representation perspective, Huang and Huang (2004) pointed out that traditional aboriginal cultures and craftsmanship are gradually disappearing. Therefore, it is necessary to take action to sustain aboriginal craftsmanship and traditional wisdom. The redevelopment of arts and crafts could resolve aboriginal employment problems and regenerate and revitalize aboriginal communities. Cohen (1988a) argued that the inauthentic can become authentic given that authenticity is constructed. Tourism media such as travel brochures and tour guides, both written and oral, deliver histories and interpret local culture to tourists, often leading to perceptions of authenticity whether or not the experiences that are gained have objective authenticity (Wang, 1999). Thus, the form and content of cultural communication are important (Buzinde, Santos, \& Smith, 2006), and they occur through cultural representation, i.e. people, things or objects that symbolize and represent the culture. Feelings of authenticity are produced and consumed (Hall, 1997) and are rooted in the process of cultural representation, which, ultimately, influences the conservation, recreation and sale of tradition. Thus, authenticity, often expressed by a form of cultural representation, is pivotal for cultural heritage tourism (Kolar \& Zabkar, 2009).

In summary, most scholars exploring the issue of authenticity now acknowledge that authenticity is not inherent but is constructed, and they approach the concept through perceptions (Chhabra et al., 2003; McIntosh \& Prentice, 1999; Revilla \& Dodd, 2003; Shackley, 1996). In the domain of heritage management and planning, the concept of stakeholders' perceptions is receiving more and more attention, not only because they have legal status and rights in making decisions but also because their views influence the acceptability of initiatives (Aas, Ladkin, \& Fletcher, 2005; Nicholas, Thapa, \& Ko, 2009). In tourism studies, the most commonly discussed stakeholders include representatives of local communities, tourists, governmental officers and private entrepreneurs (Nicholas et al., 2009). Yang and Wall (2009) invited these stakeholders, including minority people, to participate in their studies of ethnic tourism in China. They found that important decision-makers were not minority people and their viewpoints on 
authenticity and cultural representation were different from local people's viewpoints. Nevertheless, studies concerning the perceived authenticity of aboriginal handicrafts or souvenirs are scant; consequently, this research aims to understand cultural representation and the authenticity of tourism souvenirs as determined by various stakeholders, especially tourists, by using a case study.

\section{Study Area}

This study focuses on the perceptions of the glass beads that are produced by the Paiwan tribe for their own use as cultural artifacts and for sale to tourists as souvenirs. According to Huang and Huang (2004), Paiwan have three "treasures": glass beads, painted pottery and bronze knives (Tukuzan). Glass beads have considerable cultural importance and are collected or worn as jewelry. Accordingly, this research explores glass beads as an example to explore the perceived authenticity of aboriginal tourism souvenirs.

Many Paiwan people live in Pintung County, Taiwan. Most residents of San Di Man Township in Pintung County, in the south of Taiwan, are Paiwan tribal people, and it is the major production center of glass beads in Taiwan. San Di Man has become famous among tourists as a place to visit and experience glass bead culture. In fact, one of the best-selling Taiwanese movies, "Cape No. 7", was shot in San Di Man and used glass bead handicrafts to symbolize the unwavering pursuit of love and the attachment of the people to the place. Following the success of this movie, glass beads were used as the basis of a cultural tourism initiative involving the development of a cultural village. In 2009, San Di Man was put forward as the representative of the Pintung Country to compete under the "Local Business District Invigoration and Revitalization Plan" organized by the Department of Commerce (DOC), Ministry of Economic Affairs (MOEA), Taiwan. It was highly recommended and has become the first aboriginal business district to specialize in indigenous handicrafts (DOC, MOEA, 2010).

\section{Methods}

This research adopts a mixed methods approach so as to have the advantages of both qualitative and quantitative studies. Prior to conducting surveys, in-depth interviews were undertaken to explore perceived authenticity from the perspectives of various stakeholders. Afterwards, the main themes identified in transcriptions of these interviews, in conjunction with survey instruments from relevant literature, were used to design the questionnaire that was used in this research. Participant observation and document analysis were also used in the qualitative approach.

\section{In-depth Interviews}

In-depth interviews are a means to exchange or construct deep meanings from research subjects. They are an appropriate method to explore interviewees' feelings, ways of thinking, intentions or explanations regarding events or issues (Patton, 1990). Holstein and Gubrium (1995) and Marshall and Rossman (1995) indicated that in-depth interviews can be used to capture interviewees' perceptions and understandings of research themes. Therefore, in-depth interviews were conducted in November 2009 in San Di Man Township in Pintung County, Taiwan. Craftsmen and operators from three renowned glass bead work- 
shops in San Di Man were interviewed, as well as tourists, local residents and government employees, i.e. the people in charge of the Tourist Service Center in San Di Man, and supervisors working in the Indigenous Peoples Culture Park, the only governmental aboriginal theme park supervised by Council of Indigenous Peoples, Executive Yuan in Taiwan. It is located only a 10 -minute drive from the San Di Man glass bead industry. In addition, introductory information on glass beads, and printed travel brochures and pamphlets made by glass bead workshop operators were collected to supplement the interviews.

Judgmental sampling was used to select respondents for the qualitative approach (Crabtree \& Miller, 1999) and in-depth interviews were terminated once no new information was obtained, according to the principle of data saturation (Bogdan \& Biklen, 2001). Items for indepth interviews were based, in part, on the studies of Blundell (1993) and Medina (2003). The former explored souvenir shopping in First Nations tourism in Canada whereas the latter investigated the influence of tourism on the commercialization of Mayan handicrafts in Mexico. Also, five elements addressing the tourists' perceived authenticity of local handicrafts were adopted from Revilla and Dodd (2003). Hence, 13 questions were used to guide the interviews (Table 1). In all, 24 interviews were undertaken for this part of the study. The characteristics of respondents will be described below.

Validity and reliability were both addressed. Face validity was checked by inviting three experts and scholars to check and discuss all interview questions (Wimmer \& Dominick,

Table 1 Items for In-depth Interviews

1. Do you know the types and traditional names of glass beads?

2. What is your understanding about glass beads of the Paiwan tribe, e.g. definition, symbolic meanings, story lines?

3. What meaning do glass beads have for you?

4. (a) Did you purchase glass beads?

(b) Why did you purchase glass beads? For what purpose did/will you use the glass beads?

(c) How will you share the glass beads you bought with others?

5. What meanings do you think glass beads represent for mainstream society?

6. Do you think tourism souvenirs, such as glass beads, should possess authenticity? Why?

7. What appearances do you think glass beads should possess to be authentic?

8. What functions do you think glass beads should have in order to be authentic?

9. What traditional characteristics do you think glass beads should have to be authentic?

10. In addition to an authentification or guarantee certificate, how can the perception of authenticity of glass beads be enhanced?

11. Where do you think authentic glass beads should be displayed or produced?

12. How do you think Paiwan artists should make glass beads that are both authentic and economically beneficial?

13. Besides being original or handmade, how should authentic glass beads be made to be both authentic and profitable? 
1991). Internal consistency between two coders (or judges) was satisfied by achieving $80 \%$ agreement in inter-coder and intracoder reliability with the third coders (Kassarjian, 1977; Keaveney, 1995).

\section{Survey Instrument}

The survey instrument was adapted mainly from the studies of Chang et al. (2008) and Revilla and Dodd (2003), both of which explored cultural heritage and tourism souvenirs. The questionnaire, which was also informed by the in-depth interviews, is divided into two parts. The first part explores the perceived authenticity of glass beads among tourists who visit tribal communities in the south of Taiwan. In total, 20 items were posed, including appearance, utility, traditional characteristics, certification, difficulty of acquisition, local production and low cost. The second part solicits information on the tourists and their travel characteristics, including items such as gender, age, education, place of residence and aboriginal status. A five-point Likert-type scale (from $5=$ strongly agree to 1 $=$ strongly disagree) was used to assess perceptions of authenticity.

\section{Reliability and Validity, Sampling, Data} Collection and Statistical Analyses

Prior to undertaking the formal survey, a pilot study was administered in January 2010 to confirm that the internal consistency and reliability of survey items were acceptable. Also, experts and tourism scholars familiar with glass beads or aboriginal heritage were invited to discuss survey items so as to meet face validity.
The formal survey was undertaken during the 2010 Lunar Chinese New Year holiday in three renowned handicraft stores in San Di Men Township, Pintung County. A purposive sampling method was used. Four hundred and seven valid questionnaires were obtained from tourists who had been to one of three workshops on glass beads and were 18 years old and above (Chang, Wall, \& Tsai, 2005). Statistical analyses such as frequencies, reliability test, independent $t$-tests, analysis of variance and post hoc tests were administered.

\section{Findings}

The qualitative results from the in-depth interviews and the quantitative analyses of the questionnaire surveys will be presented in turn.

\section{Qualitative Results and Discussion}

Twenty-four individuals were interviewed: six local governmental officials, six residents, six personnel of glass bead workshops and six tourists. Figure 1 shows the inputs of four key stakeholder groups identified previously by Xie and Wall (2003). After transcribing recorded transcripts and research notes and correcting a few spellings, information was separated into four units of analysis: governmental employees, residents, tourism entrepreneurs and tourists. Then, 747 coded items were specified from a content analysis, including words, phrases and simple sentences (Berg, 1998). Sample elements of categories include "understanding the meaning of glass beads", "the importance of being authentic", "economic benefits" and "functions". In the end, 188 categorized items were condensed and labeled from the 747 units by inviting judges 


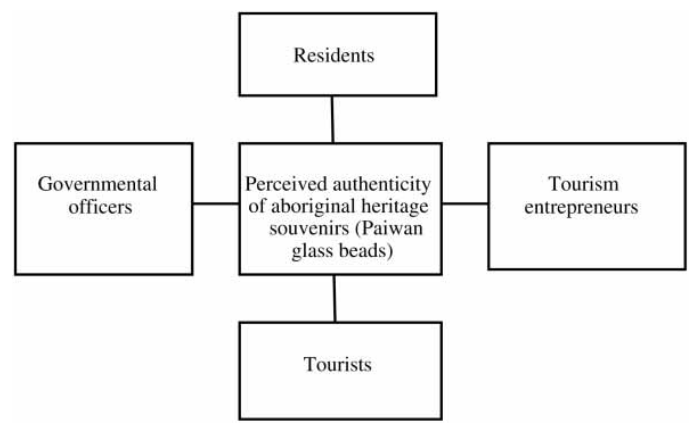

Figure 1 Conceptual Framework (After Xie \& Wall, 2003).

to re-judge the coding after a 2-week break, as suggested by Davis and Cosenza (1993), and these were summarized into 14 themes as follows.

1. Types of glass bead. A government officer said that, "Each and every glass bead represents different stories. For instance, the bead of land means you must be the leader of the tribe so you have the power of owing the land. The so-called bead of 'hands and feet' refers to girls because they must learn how to use their hands to make beads and also use their feet to work the traditional weaving machine to make clothes". A glass bead workshop operator indicated that, "Some names of glass beads are similar to the interpretation of Paiwan language such as the bead of 'Glory and beauty' means sunshine". One tourist indicated that, "Through the accumulation of time, I am pleased to learn the meanings and types of glass beads by their representations. I think it is pretty cool".

2. Identities and meanings of glass beads.

a. The Paiwan's reputation for making glass beads is also the basis of their aristocratic system. According to the Paiwan tra- dition, only heads or nobles of Paiwan tribes can possess glass beads. Thus, glass beads are used as identity symbols and reflect hierarchical social structure of Paiwan. As female noble members do not need to engage in daily production activities, they are able to spend most of their time on handicrafts, such as embroidery and glass bead creation. This demonstrates their social status and also fulfills their emotional desire for beauty. Also, glass beads are indispensible components of important events, e.g. weddings, harvest days or funerals, and express particular blessings. One Paiwan informant mentioned, "One can really tell the differences between nobles and normal people by telling whether or not they are wearing glass beads during important events". Another indicated, "Whenever Paiwan people get married, the head of the tribe uses a glass bead necklace to give the couple a blessing by circling a few rounds on top of the bride's head. Afterwards, he says a few words to the couple then gives the necklace to the bride to wear".

b. Glass beads are arranged in sequence. A glass bead operator explained that, "According to traditional Paiwan 
customs, only two or three glass beads of a necklace, recognized as heritage glass beads, for instance, were passed down from the original ancestors. From generation to generation, more glass beads were added so as to make a long necklace. Thus, an intra-family mixed glass bead necklace contains the meaning of family inheritance".

c. Rich and symbolic meanings. Glass beads have underlying meanings according to Paiwan myths and tradition. A Paiwan informant said, "A glass bead, for us, is always recognized as a spiritual symbol. Each and every single piece contains unique meaning”.

d. Beautiful and precious heritage. Glass beads are the most popular handicraft for Paiwan to display their cultures aesthetically. The older a glass bead is, the more holy meaning it possesses. Therefore, Paiwan people enshrine and worship glass beads. One art studio worker stressed that, "Glass beads are a very, very important cultural heritage asset for Paiwan culture and society".

e. Gifts to express appreciation or recognition. A glass bead necklace is used as a gift to indicate appreciation. As one officer working for Indigenous Cultures Park explained: "Heads or elder leaders of the Paiwan give glass bead necklaces to warriors or persons who make a significant contribution to tribal people or communities".

3. Group differences in meanings. Local people believe it is necessary to understand Paiwan culture through awareness of the symbolic meanings of glass beads. As one resident mentioned: "Glass beads are very precious and almost every single family collects glass beads from their ancestors. It is vital to let young Paiwan people know the cultural meanings of glass beads so they will educate their friends (non-aborigines)". However, glass beads mean varied things to tourists. For instance, one interviewee said, "I will not buy something that is not attractive to me ... I bought glass beads as a souvenir because they look beautiful; in turn, I got to know the cultural meanings of the piece I bought". Another tourist indicated, "The most famous souvenir in San Di Men is glass beads. You know, most of my friends have never been to this area so I bought some glass bead pieces in order to show my friends I have been to San Di Men and have some contacts with Paiwan cultures". However, for some tourists glass beads are not seen as cultural products. One tourist reflected, "My friends know I am coming to this area, so they asked me to buy some attractive glass beads for them. For me, they are just a commodity".

4. Purchase of glass bead souvenirs. Most (over $80 \%$ ) of the interviewees indicated they had bought glass beads in San Di Men. Those who did not buy glass beads indicated that they already had glass beads at home: "Although I did not buy glass beads this time, my friends have given me them as souvenirs before".

5. Purposes of buying glass beads. Beads were bought as gifts, for curiosity and out of personal interest, for a personal collection and as a gesture of blessing.

6. Sharing of glass bead stories. Workshop operators often give guests a brief introduction to the meanings of glass beads. One operator said: "I always tell tourists the stories behind each type of glass bead. Tourists are intrigued by this type of story-telling and reasons behind the 
colors, shapes, and arrangements of glass beads". Some tourist interviewees were surprised to learn that glass beads, like human beings, are divided into male and female types. Male beads are generally bigger than female ones. One tourist noted: "I will definitely tell my friends all they wish to know about glass beads after this trip. Particularly, I will remind them of the difference between male and female glass beads so they will not buy the wrong ones in the future; females should buy the female glass beads while males should buy the males ones!" Besides, tourists all agreed that it is very helpful to read the pamphlets that introduce types and basic meanings of glass beads and provide photos of each type of bead. After participating in making a glass bead piece themselves, interviewees commented that they would encourage their friends or families to give it a try if traveling to San Di Men.

7. Meanings of glass beads for non-aboriginal visitors. Most non-aboriginal tourists agreed that it is important to preserve Paiwan culture, especially the collecting of glass beads with heritage values, and passing them down from generation to generation. Nevertheless, some interviewees believed that glass beads are packaged to satisfy tourists' tastes so they are nothing more than souvenirs. One tourist even mentioned that, "Somehow, I feel these glass beads are inauthentic despite the fact that I do enjoy learning the stories behind them: each and every story is quite interesting".

8. The importance of authenticity. The majority of interviewees viewed authenticity as being an important attribute of acceptable souvenirs. However, one tourist emphasized: "I buy souvenirs as long as I am fond of them. I do not care whether souvenirs are authentic or not". Another argued: "Well, it is really not that important for me to look for authenticity of souvenirs. After all, souvenirs are just one type of commodity. I am quite happy with attractively-designed souvenirs".

9. The appearance and traditional characteristics of glass beads. For government officers and local residents, glass beads should not have flat surfaces, and traditional motifs are very important aspects of authentic glass beads. For tourism industry operators, glass beads should possess traditional colors, followed by traditional motifs. As for tourists, traditional motifs were seen as being the most important characteristic.

10. Functions of glass beads. Glass beads are indispensable elements of Paiwan embroidery and accessories. Local people are used to the display of glass beads because local government officials often borrow glass beads from private collectors or local museums for display purposes to promote aboriginal events. Industry people adapt the glass beads to respond to market preferences.

11. Proof of authenticity. Most stakeholders viewed the pamphlet that introduced the artist as well as the certificate of authenticity as confirming the authenticity of glass beads. However, slightly different opinions came from government officers and tourists. For instance, one government interviewee argued: "I like to see stores or workshops have people to give visitors a professional briefing on glass beads". A young tourist noted: "I will perceive glass beads as authentic as long as the artist is making the glass beads on site. It would be cool if I could take 
photos with the artist and the piece I bought!"

12. Sources of glass beads. The majority of interviewees believed the best places to get authentic glass beads are from workshops or their sales outlets in other places. For example, the Dragon Fly Workshop has a sales outlet near the boarding gate within the Taoyuan International Airport near Taipei.

13. The production of glass bead souvenirs. Tourists have slightly different perceptions of authenticity compared with other stakeholders. Governmental officers, workshop operators and local people perceived glass beads to be authentic if they were made by Paiwan out of silicon. Most tourists believed that only glass bead pieces made and sold in workshops operated by Paiwan are authentic.

14. The benefits of glass beads. All interviewees agreed that events or special activities organized by local or central governments and media marketing result in major economic benefits from the sale of glass beads.

From the above interview results it can be seen that glass beads, the most well-known cultural symbol of the Paiwan tribe, contain a variety of meanings, as follows. They reflect the Paiwan tribe's hieratical system. The bead sequences of the necklaces follow an order that has cultural meaning, including the expression of differences between males and females, and tribal stories. They are believed to have supernatural powers. For tribal people, they are the most precious jewelry. Hence, glass beads are used to indicate status, gender, good fortune and aesthetics. For tourists, they are desirable souvenirs, although with the purchase of beads comes concerns about authenticity.
Tourists' concerns will be explored further through analysis of a visitor survey.

\section{Quantitative Results and Discussion}

Four hundred and seven questionnaires were completed. Most (89.4\%) respondents were not aboriginal. A small majority $(53.3 \%)$ were female and single $(63.9 \%)$. With respect to age, the largest group of respondents was 21-30 years old $(39.3 \%)$. Most had a college degree $(63.1 \%)$ and came from southern Taiwan $(61.4 \%)$. Almost a third was students $(31.9 \%)$, followed by employees in service industries $(19.2 \%)$ and business $(11.5 \%)$.

With reference to travel attributes of respondents, half $(50.9 \%)$ of respondents used word of mouth as an information source, followed by the Internet $(16.5 \%)$. Almost all $(91.4 \%)$ were independent travelers. However, most traveled with others: friends or colleagues $(50.6 \%)$, followed by families with children $(18.9 \%)$ and married couples $(13 \%)$. The majority $(60 \%)$ was repeat visitors and had been to other aboriginal communities (69.3\%). Thus, most had previous experience with and a basic understanding of the nature of aboriginal tourism. More than half $(59.5 \%)$ of respondents spent half to a full day in the study sites, while less than $20 \%$ of respondents stayed overnight. Almost half $(41.3 \%)$ purchased a souvenir and almost all of these people purchased glass beads. However, only $15.5 \%$ of respondents experienced glass bead production, making bead products themselves, which normally costs less than US\$10 per person.

With respect to determinants of perceived authenticity of beads, of the Likert scales, "traditional characteristics" was accorded the highest mean score $($ mean $=4.247)$. Also, items such as "uses traditional method of pro- 
duction", "designs possess traditional motifs", "uniqueness" and "tribal motifs" were also seen as indicators of authenticity. Glass beads are designed to be seen and, thus, it is not surprising that many tourists judge authenticity by appearance, including colors and designs, and "appearance" was, in fact, identified as an important criterion. "Hard to obtain" was also regarded as being an important indicator. These findings corroborate the insights gained from the qualitative interviews.

Major differences were not found in association with demographic attributes or trip characteristics. For example, previous visits to other aboriginal sites were not associated with a significant difference in perceived authenticity of glass bead souvenirs. This should not be surprising because Taiwan has 14 officially recognized aboriginal cultures, each possessing its own arts and crafts; so aboriginal products are diverse. However, repeat visitors to San Di Men appeared to have more understanding and tourists who purchased glass bead souvenirs were inclined to be less demanding than repeat visitors with respect to authenticity. Furthermore, aboriginal respondents placed more emphasis on the authenticity of glass beads. Respondents from eastern Taiwan (e.g. Hualien or Taitung County) scored higher on authenticity measures compared with respondents from northern or central Taiwan, confirming the findings of Chang et al. (2008), that perhaps they have more opportunities to experience aboriginal cultures and to interact with aboriginal people because most aborigines live in eastern Taiwan.

\section{Conclusions and Implications}

This study explored the perceived authenticity of aboriginal cultural heritage products and how these perceptions vary between different stakeholders. It builds upon the concepts of culture heritage, aboriginal tourism, souvenirs and authenticity and the links that exist between them. We have highlighted the complexity of these relationships and have shown that Paiwan beads have multiple meanings, even to the Paiwan themselves. Thus, authenticity means different things to different stakeholders and, therefore, there is not one authenticity. Even within the Paiwan culture the design and meaning of beads have changed over time and differ among individuals, and the sale of beads as souvenirs to tourists is adding to these complexities.

Most previous studies focusing on authenticity in tourism used qualitative methods and relatively few have employed quantitative approaches. This study may be the first to use mixed methods to explore the authenticity of aboriginal cultural heritage souvenirs and how these may vary between stakeholders and among tourists with different characteristics. Consequently, both the methods and the findings could serve as a valuable reference for both aboriginal people and heritage management in places where cultural diversity is an important theme.

For future tourism development, glass bead cultures should be efficiently marketed and promoted. However, beads alone are probably insufficient to constitute a marketable tourism product that will provide satisfying experiences for visitors. Therefore, it is necessary for the Paiwan to consider the overall experiences offered to visitors. A cultural district focusing on glass beads could be established that also provides aboriginal performances, cuisines and homestays, and even a spa could be established, thereby attracting visitors who might subsequently learn to appreciate Paiwan culture more generally and purchase glass beads. Such an aboriginal lifestyle area would enable the beads to be placed in context better, and 
would provide a more holistic cultural experience for visitors, encouraging them to stay longer and spend more money. With respect to the glass bead workshops, more and better spaces could be designed to attract more people to experience the making of glass beads. Also, well-designed certificates of authenticity should be provided. This could be part of a branding initiative to encourage visitors, particularly international visitors, to buy and even collect glass beads. Glass bead exhibitions should be held in museums and galleries throughout the country to present them as an artistic, not merely a cultural, product. Local government could take the lead in encouraging the formation of strategic alliances among workshops, restaurants, homestays and research and development institutes to enhance the tourism product.

More research could be undertaken. This research was undertaken in winter and early spring owing to the weather and other events: earthquakes and mudslides during the summer and early fall prevented people visiting San Di Men. Not only was this an economic blow to the community, but it also prevented research from being undertaken in what is usually the peak season, especially for domestic visitors. There is also a need to undertake similar research into the cultural symbols and tourism products of other tribes.

Although numerous tourism scholars have written on authenticity, it is still a problematic concept. This study extends understanding of perceived authenticity in aboriginal tourism, which is an important but underexplored topic in tourism studies. A better understanding of the essence of authenticity as perceived by different stakeholders will enrich interpretation of the concept. In addition, the research findings offer the aboriginal destinations information that is useful to them in enhancing and marketing their products.

\section{Acknowledgement}

The first author is grateful for the funding support provided by the National Science Council of Taiwan (99-2410-H-034-054).

\section{References}

Aas, C., Ladkin, A., \& Fletcher, F. (2005). Stakeholder collaboration and heritage management. Annals of Tourism Research, 32(1), 28-48.

Anderson, L.F., \& Littrell, M.A. (1995). Souvenir-purchase behavior of women tourists. Annals of Tourism Research, 22(2), 328-348.

Apostolakis, A. (2003). The convergence process in heritage tourism. Annals of Tourism Research, 30(4), 795-812.

Appadurai, A. (1986). Introduction: In the social life of things: Commodities in cultural perspective. Cambridge, UK: Cambridge University Press.

Asplet, M., \& Cooper, M. (2000). Cultural design in New Zealand souvenir clothing: The question of authenticity. Tourism Management, 21(3), 307-312.

Berg, B.L. (1998). Qualitative research methods for the social sciences. Needham Heights, MA: Allyn \& Bacon.

Blundell, V. (1993). Aboriginal empowerment and souvenir trade in Canada. Annals of Tourism Research, 20(1), 64-87.

Bogdan, R.C., \& Biklen, S.K. (2001). Qualitative research for education: An introduction to theory and methods. New York: Allyn and Bacon.

Boorstin, D.J. (1992). The image: A guide to pseudoevents in America. New York: Vintage Books.

Buzinde, C.N., Santos, C.A., \& Smith, S.J. (2006). Ethnic representations: Destination imagery. Annals of Tourism Research, 33(3), 707-728.

Chang, J. (2006). Segmenting tourists to aboriginal cultural festivals: An example in the Rukai tribal area, Taiwan. Tourism Management, 27(6), 1,224-1,234.

Chang, J., Wall, G., \& Chang, C.-L. (2008). Perception of the authenticity of Atayal woven handicrafts in Wulai, Taiwan. Journal of Hospitality and Leisure Marketing, 16(4), 385-409.

Chang, J., Wall, G., \& Chu, S.-T. (2006). Novelty-seeking at aboriginal attractions. Annals of Tourism Research, 33, 729-747.

Chang, J., Wall, G., \& Lai, C.A. (2005). The advertising effectiveness of aboriginal endorsers: An example Taiwan. Tourism Analysis, 10(3), 247-255. 
Chang, J., Wall, G., \& Tsai, C.-T. (2005). Endorsement advertising in aboriginal tourism: An experiment in Taiwan. International Journal of Tourism Research, 7(6), 347-356.

Chhabra, D., Healy, R., \& Sills, E. (2003). Staged authenticity and heritage tourism. Annals of Tourism Research, 30(3), 702-719.

Cohen, E. (1988a). Authenticity and commoditization in tourism. Annals of Tourism Research, 15(3), 371-386.

Cohen, E. (1988b). Tradition in the qualitative sociology of tourism. Annals of Tourism Research, 15(1), 29-46.

Crabtree, B.F. \& Miller, W.L. (1999). Doing qualitative research (2nd ed.). California: Sage.

Davis, D., \& Cosenza, R.M. (1993). Business research for decision making. California: Wadsworth Publishing.

D'hauteserre, A.-M. (2010). Government policies and indigenous tourism in New Caledonia. Asia Pacific Journal of Tourism Research, 15(3), 285-303.

Department of Commerce, Ministry of Economic Affairs, Taiwan (DOC, MOEA) (2010). San Di Man, Pintung Country: Local Business District Invigoration and Revitalization Plan, Retrieved March 21, 2010, from http:// gcis.nat.gov.tw/taiwan-go/LocalBrand/Index.aspx

Dougoud, R.C. (2000). Souvenirs from Kambot (Papua New Guinea): The sacred search for authenticity. In M. Hitchcock \& K. Teague (Eds.), Souvenirs: The material culture of tourism (pp. 223-237). Ashgate: Aldershot.

Fischer, S. (1999). Living history. North Carolina, April (2), 8.

Fyall, A., \& Garrod, B. (2001). Heritage tourism: At what price? Managing Leisure, 3(4), 213-228.

Goeldner, C.R. \& Ritchie, J.B. (2002). Tourism, principles, practices, philosophies (9th ed.). New York: John Wiley.

Goffman, E. (1959). The presentation of self in everyday life. New York: Doubleday.

Graham, B., Ashworth, G. J. \& Tunbridge, J.E. (2000). A geography of heritage: Power, culture and economy. London: Arnold.

Halewood, C., \& Hannam, K. (2001). Viking heritage tourism. Annals of Tourism Research, 28(3), 565-580.

Hall, D.R., \& Zeppel, H. (1990). Cultural and heritage tourism: The new grand tour? Historic Environment, 7(3-4), 86-98.

Hall, S. (Ed.). (1997). Representation: Cultural representations and signifying practices (pp. 1-74). London: Sage and the Open University Press.

Hinch, T. \& Butler, R. (1996). Indigenous tourism: The four H's. In R. Butler \& T. Hinch (Eds.), Tourism and indigenous peoples, (pp. 3-19). London: International Thomson Business Press.

Hitchcock, M. \& Teague, K. (2000). Souvenirs: The material culture of tourism. Aldershot: Ashgate.

Holstein, J., \& Gubrium, J. (1995). The active interview. Newbury Park, California: Sage.

Hsieh, S.C. (1999). Representing aborigines: Modelling Taiwan's 'mountain culture'. In K. Yoshino (Ed.), Consuming ethnicity and nationalism: Asian experiences (pp. 89-110). Richmond, Surrey: Curzon.

Huang, H.-S. \& Huang, C.-C. (2004). The total assessment of aboriginal cultural industries. Taipei: Yun-Liu Publishing Co.

Hunter, W.C., \& Suh, Y.K. (2007). Mutimethod research on destination image perception: Jeju standing stones. Tourism Management, 28(1), 130-139.

Jansen-Verbeke, M. (1998). The synergism between shopping and tourism. In W. Theobald (Ed.), Global tourism (pp. 428-445). Oxford: Butterworth-Heinemann.

Kassarjian, H.H. (1977). Content analysis in consumer research. Journal of Consumer Research, 4(1), 8-18.

Keaveney, S.M. (1995). Customer switching behavior in service industries: An exploratory study. Journal of Marketing, 59(2), 71-82.

Kerstetter, D.L., Confer, J.J., \& Graefe, A.R. (2001). An exploration of the specialization concept within the context of heritage tourism. Journal of Travel Research, 39(3), 267-274.

Kolar, T., \& Zabkar, V. (2009). A consumer-based model of authenticity: An oxymoron or the foundation of cultural heritage marketing? Tourism Management, 31(5), $1-13$.

Littrell, M.A., Anderson, L.F., \& Brown, P.J. (1993). What makes a crafts souvenir authentic? Annals of Tourism Research, 20(1), 197-215.

Marshall, C., \& Rossman, G. (1995). Designing qualitative research (2nd ed.). Newbury Park, CA: Sage.

Mcintosh, A.J. \& Goeldner, C. (1995). Tourism: Principles, practices, philosophies (7th ed.). New York: John Wiley \& Sons.

Mcintosh, A.J., \& Prentice, R.C. (1999). Affirming authenticity: Consuming cultural heritage. Annals of Tourism Research, 26(3), 589-612.

Medina, L.K. (2003). Commoditizing culture tourism and Maya identity. Annals of Tourism Research, 30(2), 353-368.

Nicholas, L.N., Thapa, B., \& Ko, Y.J. (2009). Residents' perspective of a world heritage site: The Pitons management area, St. Lucia. Annals of Tourism Research, 36(3), 390-412. 
Notzke, C. (1999). Indigenous tourism development in the arctic. Annals of Tourism Research, 26(1), 55-76.

Nuryanti, W. (1996). Heritage and postmodern tourism. Annals of Tourism Research, 23(2), 249-260.

Patton, M.Q. (1990). Qualitative evaluation and research methods (2nd ed.). California: Sage.

Pine, B.J., \& Gilmore, J.H. (1999). The experience economy: work is theatre \& every business a stage. Boston: Harvard Business School Press.

Poria, Y., Butler, R., \& Airey, D. (2003). The core of heritage tourism. Annals of Tourism Research, 30(1), 238-254.

Prentice, R. (1993). Tourism and heritage attractions. London: Routledge.

Ramshaw, G., \& Gammon, S. (2005). More than just nostalgia? Exploring the heritage/sport tourism nexus. Journal of Sport Tourism, 10(4), 229-241.

Redfoot, D. (1984). Touristic authenticity, touristic angst, and modern reality. Qualitative Sociology, 7(4), 291-309.

Revilla, G., \& Dodd, T.H. (2003). Authenticity perceptions of Talavera pottery. Journal of Travel Research, 42(3), 94-99.

Ryan, C., \& Huyton, J. (2002). Tourists and aboriginal people. Annals of Tourism Research, 29(3), 631-647.

Schouten, F. (2006). The process of authenticating souvenirs. In M. Smith, \& M. Robinson (Eds.), Cultural tourism in a changing world: Politics, participation and (re)presentation (pp. 191-202). New York: Channel View Publications.

Shackley, M. (1996). Too much room at the inn? Annals of Tourism Research, 23(2), 449-462.

Sharpley, R. (1999). Tourism, tourists and society (2nd ed.). Cambridge, UK: ELM.

Smith, V.L. (1996). Indigenous tourism: The four H's. In R. Butler \& T. Hinch (Eds.), Tourism and indigenous peoples, (pp. 283-307). London: International Thomson Business Press.

Steiner, C.J., \& Reisinger, Y. (2006). Understanding existential authenticity. Annals of Tourism Research, 33(2), 299-318.

Stoffle, R.W., \& Evans, M.J. (1990). Holistic conservation and cultural triage: American Indian perspectives on cultural resources. Human Organization, 49(2), 91-99.

Swanson, K. (1994). Souvenir marketing in tourism retailing: Shopper and retailer perceptions. Unpublished doctoral dissertation, Texas Tech University, Lubbock, Texas.
Taylor, J. (2001). Authenticity and sincerity in tourism. Annals of Tourism Research, 28(1), 17-26.

Timothy, D.J. \& Boyd, S.W. (2003). Heritage tourism. Harlow: Prentice Hall.

Toyota, M. (2006). Consuming images: Young female Japanese tourists in Bali, Indonesia. In K. Meethan, A. Anderson, \& S. Miles (Eds.), Tourism consumption and representation: Narratives of place and self (pp. 158-177). Cambridge, MA: CAB International.

Van Den Berghe, P.L., \& Charles, F.K. (1992). Tourism and the ethnic division of labor. Annals of Tourism Research, 19(1), 234-249.

Waitt, G. (2000). Consuming heritage: Perceived historical authenticity. Annals of Tourism Research, 27(4), 835-862.

Wang, N. (1999). Rethinking authenticity in tourism experience. Annals of Tourism Research, 26(2), 347-370.

Williams, S. (1998). Tourism geography. London \& New York: Routledge.

Wimmer, R.D., \& Dominick, J.R. (1991). Mass media research. Belmont, CA: Wadsworth.

Xie, P. \& Wall, G. (2003). Authenticating visitor attractions based upon ethnicity. In A. Fyall, A. Leask \& B. Garrod (Eds.), Managing visitor attractions: New directions, (pp. 107-123). Oxford: Butterworth Heinemann.

Yale, P. (1991). From tourist attractions to heritage tourism. Huntingdon: ELM Publications.

Yang, L., \& Wall, G. (2008). Ethnic tourism and entrepreneurship: Xishuangbanna, Yunnan, China. Tourism Geographies, 10(4), 522-544.

Yang, L., \& Wall, G. (2009). Ethnic tourism: A framework and an application. Tourism Management, 30(4), 557-570.

Yang, L., Wall, G., \& Smith, S. (2008). Ethnic tourism development: Chinese government perspectives. Annals of Tourism Research, 35(3), 751-771.

Yeoman, I., Brass, D., \& Mcmahon-Beattie, U. (2007). Current issue in tourism: The authentic tourist. Tourism Management, 28(4), 1128-1138.

Yoshimura, M. \& Wall, G. (2010). The reconstruction of Atayal identity in Wulai, Taiwan. In M. Parnwell \& M. Hitchcock (Eds.), Heritage tourism in Southeast Asia. Copenhagen: NIAS Press (Nordic Institute of Asian Studies).

Zeppel, H.D. (1999). Touring aboriginal cultures: Encounters with aboriginal people in Australian travelogues. Tourism, Culture and Communication, 2(3), 123-141. 